\title{
Increase in Circulating and Adipose Tissue Expression of Secretory Leukocyte Peptidase Inhibitor (SLPI) with Obesity and Diabetes
}

\author{
Nigel Hoggard*, Morven Cruickshank, and Kim-Marie Moar
}

\author{
Rowett Institute of Nutrition and Health, University of Aberdeen, Aberdeen Centre for Energy Regulation and Obesity \\ (ACERO), Bucksburn, Aberdeen, Scotland AB21 9SB.
}

\begin{abstract}
Objective: We have recently identified secretory leukocyte peptidase inhibitor (SLPI), a component of the innate host defence in human omental adipose tissue. The objective of this study was to determine if the SLPI secreted by adipose tissue is regulated by changes in obesity.

Materials/Methods: Circulating SLPI was measured in lean/overweight $(\mathrm{n}=13)$, obese $(\mathrm{n}=10)$ and obese diabetic $(\mathrm{n}=$ 11) male volunteers. SLPI gene expression was measured in subcutaneous adipose tissue fat biopsies from these volunteers using real time PCR. The regulation of SLPI was further explored in the human SGBS adipocyte cell line.

Results: Circulating SLPI shows a small but significant increase in obese $(11 \% ; p \leq 0.05)$ and obese diabetic volunteers $(16 \% ; p \leq 0.001)$ when compared with lean/overweight volunteers. There was a corresponding increase in SLPI mRNA in the adipose tissue of obese $(800 \% ; \mathrm{p} \leq 0.01)$ and obese diabetic volunteers $(500 \% ; \mathrm{p} \leq 0.001)$ compared with lean/overweight volunteers. In differentiated human adipocytes, SLPI mRNA is increased by IL-6 $(10 \mathrm{ng} / \mathrm{ml} ; 318 \% ; \mathrm{p} \leq$ $0.05)$, TNFalpha (1ng/ml; 279\%; $\leq \leq 0.005)$, LPS $(100 \mathrm{ng} / \mathrm{ml} ; 318 \% ; \mathrm{p} \leq 0.05)$, insulin $(1 \mathrm{mM} ; 321 \% ; \mathrm{p} \leq 0.05)$ and glucose $(5 \mathrm{mM} ; 246 \% ; \mathrm{p} \leq 0.05)$ while in the preadipocytes SLPI mRNA is decreased by TNF alpha $(10 \mathrm{ng} / \mathrm{ml} ; 30 \% ; \mathrm{p} \leq$ $0.05)$ and LPS $(100 \mathrm{ng} / \mathrm{ml} ; 42 \% ; \mathrm{p} \leq 0.05)$ compared to untreated preadipocytes.
\end{abstract}

Conclusions: Circulating SLPI and SLPI gene expression in subcutaneous adipose tissue increases with obesity where it may play a local role in the regulation of the low grade inflammatory response associated with obesity.

Keywords: SLPI, adipose tissue, omental, subcutaneous, metabolic syndrome.

\section{INTRODUCTION}

Obesity is characterized by a state of chronic, mild inflammation with an increase in the circulating levels of several inflammatory markers such as C-reactive peptide (CRP), interleukin 6 (IL-6), haptoglobin, serum amyloid A, tumour necrosis factor alpha (TNF alpha), and monocyte chemotactic protein-1 (MCP-1) [1, 2]. White adipose tissue (WAT) appears to be a major site of inflammation in obesity and a source of at least some of these circulating inflammatory factors. WAT is no longer considered just as a passive reservoir for the efficient storage of fuel as triglycerides, but also as an important endocrine and secretory organ that influences a range of physiological functions via the secretion of multiple protein hormones and factors [3]. The inflammation within adipose tissue plays a causal role in the initiation and development of the diseases linked to obesity - particularly type 2 diabetes, cardiovascular disease and the other components of the metabolic syndrome [2].

WAT is distributed in multiple sites within the body with a higher risk of obesity related metabolic diseases associated

*Address correspondence to this author at the Rowett Institute of Nutrition and Health, University of Aberdeen, Aberdeen Centre for Energy Regulation and Obesity (ACERO), Bucksburn, Aberdeen, Scotland AB21 9SB; Tel: 01224 438655; Fax: 01224 438629; Email: N.Hoggard@abdn.ac.uk with increased WAT in the abdominal compared with the subcutaneous region $[4,5]$. We have recently identified the expression of secretory leukocyte peptidase inhibitor (SLPI) in both human omental and subcutaneous WAT [6]. SLPI encodes a $11.7 \mathrm{kDa}$ protein secreted by neutrophils, macrophages and mucous membrane epithelial cells, whose main role is to protect epithelial tissues from serine proteases such as trypsin, leukocyte elastase, and cathepsin G $[7,8]$. SLPI possesses an immunomodulatory role regulating various factors $[7,9,10]$ with SLPI knockout mice having compromised wound healing and increased inflammation [11]. SLPI is thus a component of the innate host defence that maintains a balance between protective inflammatory responses and uncontrolled inflammation that can lead to tissue destruction and failure to heal [12].

To determine if SLPI has an immunomodulatory role in obesity and/or its associated metabolic disorders, we measured the expression of SLPI in WAT and plasma of obese volunteers with and without type 2 diabetes and compared its expression in lean/overweight volunteers. Furthermore, we explored the regulation of SLPI in the human SimpsonGolabi-Behmel syndrome (SGBS) adipocyte cell strain. 


\section{RESEARCH DESIGN AND METHODS}

\subsection{Volunteers and Protocols}

Male subjects were only included if they were not on any special religious or prescribed diet; were non-smokers and had a normal medical examination excluding, where appropriate, their diabetic status. Only those diabetic volunteers who were controlling their diabetes by diet or metformin were accepted into the study. These inclusion criteria were also checked with the participant's primary care physician. All patients provided informed written consent before inclusion in the study which was approved by the North of Scotland Research Ethics Committee (NOSREC).

Three groups of male subjects were recruited into the study (see Table 1). The study comprised a group of lean/ overweight volunteers with a waist circumference of less than 40 inches $(<101.6 \mathrm{~cm}, \mathrm{n}=13)$, an obese group with a waist circumference of greater than 40 inches $(>101.6 \mathrm{~cm}$, $\mathrm{n}=10$ ) and an obese group with a waist circumference of greater than 40 inches $(>101.6 \mathrm{~cm}, \mathrm{n}=11)$ who were diagnosed with type 2 diabetes but were controlling their diabetes by diet $(n=4)$ or metformin $(n=7$; dose 4 X 500mg/day) only. All blood samples were taken overnight fasted (10-12 hours). Waist circumference is more closely associated with obesity health risk compared with BMI [13].

\subsection{Anthropometric Measurements:}

Each subject's height, weight, waist and hip circumference were measured using standard protocols as described elsewhere [14]. Percentage body fat was determined using air-displacement whole-body plethysmography (BodPod ${ }^{\circledR}$ Body Composition System, Life Measurement Instruments, Concord, CT, USA).

\subsection{Fat Biopsies}

A subcutaneous adipose tissue biopsy was taken from the abdominal region, in subjects fasted overnight (10-12 hours). After skin disinfection, the biopsy was performed in the periumbilical triangle with a $14 \mathrm{G}$ needle, after intradermal anaesthesia with $2 \%$ lignocaine. Adipose tissue was drawn by successive suctions into a $50 \mathrm{ml}$ syringe. We routinely obtained around 1 gram of adipose tissue. Tissue was immediately frozen in liquid nitrogen and then subsequently stored at $-70^{\circ} \mathrm{C}$ prior to extraction of RNA.

\subsection{Oral Glucose Tolerance Testing (OGTT)}

Volunteers fasted (10-12 hour) overnight prior receiving an OGTT. Blood samples were taken at 0 (fasted) and 120 minutes after consuming $75 \mathrm{~g}$ of glucose. Plasma glucose levels were measured using an automated clinical analyzer

Table 1. Baseline Characteristics of the Lean/Overweight, Obese and Diabetic Study Volunteers. Lean/Overweight Volunteers have a Waist Circumference <40inches $(101.6 \mathrm{~cm})$

\begin{tabular}{|c|c|c|c|c|}
\hline \multirow{2}{*}{$\mathbf{n}$} & Lean/Overweight & Obese & Obese/Diabetic & $P$ value (Anova) \\
\hline & 13 & 10 & 11 & \\
\hline Age & $46.1(9.2)$ & $54.8(13.8)$ & $52.8(13.2)$ & 0.2 \\
\hline Waist Circumference (cm) & $89.6(5.7)$ & $113(6.5)$ & $120.2(11.5)$ & $<0.001$ \\
\hline Body Mass Index $\left(\mathrm{Kg} / \mathrm{m}^{2}\right)$ & $25.5(2.10)$ & 34.3 & 36.7 & $<0.001$ \\
\hline Height (m) & $1.76(0.64)$ & $1.78(0.08)$ & $1074(0.66)$ & 0.351 \\
\hline Body weight (kg) & $79.2(7.6)$ & $109(13.8)$ & $111(18.5)$ & $<0.001$ \\
\hline Body weight/height ratio & $0.51(0.04)$ & $0.64(0.05)$ & $0.69(0.07)$ & $<0.001$ \\
\hline Percentage body fat & $22.8(6.8)$ & $38.3(6.1)$ & $38.2(7.0)$ & $<0.001$ \\
\hline Waist: hip ratio & $0.88(0.05)$ & $0.96(0.07)$ & $1.05(0.14)$ & $<0.001$ \\
\hline Plasma cholesterol(mmol/l) & $4.73(1.32)$ & $5.24(1.06)$ & $4.38(0.49)$ & 0.17 \\
\hline Plasma HDL Cholestrol (mmol/l) & $1.28(0.33)$ & $1.15(0.34)$ & $1.19(0.27)$ & 0.54 \\
\hline Plasma LDL Cholestrol (mmol/1) & $3.08(1.11)$ & $3.38(0.80)$ & $2054(0.42)$ & 0.082 \\
\hline Triglycerides (pmol/l) & $1.09(0.52)$ & $1.42(0.53)$ & $1.80(1.08)$ & 0.04 \\
\hline OGTT Plasma Glucose $0 \mathrm{Hr}(\mathrm{mmol} / \mathrm{l})$ & $5.42(0.74)$ & $5.88(0.68)$ & $8.92(2.82)$ & $<0.001$ \\
\hline OGTT Plasma Glucose $2 \mathrm{Hr}(\mathrm{mmol} / \mathrm{l})$ & $5.22(2.13)$ & $4.75(1.3)$ & $13.8(3.80)$ & $<0.001$ \\
\hline Fasting Plasma Insulin (mU/l) & $4.74(2.77)$ & $9.81(4.03)$ & $16.3(10.6)$ & $<0.001$ \\
\hline HOMA-IR & $1.19(0.91)$ & $2.66(1.25)$ & $6.39(4.24)$ & $<0.001$ \\
\hline HOMA beta cell & $52.6(26.7)$ & $80.9(33.2)$ & $84.6(60.3)$ & 0.032 \\
\hline QUICKI & $1.12(0.22)$ & $1.44(0.21)$ & $1.66(0.24)$ & $<0.001$ \\
\hline
\end{tabular}


(Kone Oyj, Espoo, Finland; see below). Plasma insulin was measured using an ELISA assay (Mercodia, Uppsala, Sweden). The inter- and intra-assay coefficients of variation were $2.6 \%-3.6 \%$ and $2.8 \%-3.4 \%$, respectively. Homeostasis model assessment of insulin resistance (HOMA-IR= glucose $x$ insulin/22.5) was measured using the fasting glucose and insulin values [15].

\subsection{Metabolic Profile}

An automated clinical analyzer (Kone Oyj, Espoo, Finland) was used for the analysis of plasma glucose, triacylglycerol, LDL, HDL and cholesterol using commercial kits (Microgenics Gmbh; Hemel Hempstead, Herts., UK).

\subsection{Plasma ELISAs}

Plasma secretory leukocyte peptidase inhibitor (SLPI), leptin and C-reactive peptide (CRP) were detected using commercial ELISA kits according to the manufacturer's instructions (R\&D Systems, Abingdon, UK). All samples were run in duplicate. The minimum level of detection of SLPI was less than $25 \mathrm{pg} / \mathrm{ml}$ and the intra- and inter-assay coefficients of variation (CVs) were $8.0 \%$ and $8.0 \%$, respectively. The recovery of SLPI added to plasma was approximately $96 \%$. No cross-reactivity with a wide range of inflammatory markers was detected (see http://www.rndsystems.com/ pdf/dpi00.pdf). For leptin the intra- and inter-assay coefficients of variation (CVs) were 3.2 and $4.2 \%$, respectively. For CRP the intra- and inter-assay coefficients of variation (CVs) were $8.7 \%$ and $8.7 \%$, respectively.

\subsection{Cell culture-human Adipocyte SGBS Cells}

The human Simpson-Golabi-Behmel syndrome (SGBS) preadipocyte cell strain [16] used in this study was a gift from Prof M. Wabitsch, University of Ulm, Germany. The cells were cultured at $37^{\circ} \mathrm{C}$ in a humidified atmosphere of $5 \% \mathrm{CO}_{2}$ and $95 \%$ air. The cells were maintained in a basal culture medium containing the following: DMEM/Nutrient mix F12 supplemented with $8 \mathrm{mg} / 1$ Biotin, $4 \mathrm{mg} / 1$ Pantothenate, $10 \mathrm{ml} / 1$ Penicillin/Streptomycin and 10\% heat inactivated foetal calf serum (Invitrogen Ltd, Paisley, UK). To differentiate the preadipocytes into mature adipocytes, the cells were grown to near confluence (80-90\%), washed 3 times with PBS and incubated for 4 days in differentiation media containing serum free basal media plus $0.01 \mathrm{mg} / \mathrm{ml}$ human transferrin (Sigma-Aldrich, Gillingham, UK), $20 \mathrm{nM}$ insulin (Sigma-Aldrich), 0.1 $\mu \mathrm{M}$ cortisol (Sigma-Aldrich), $0.2 \mathrm{nM} \mathrm{T3}$ (Triiodo-L-Thyronine; Sigma-Aldrich), 25nM dexamethasone (Sigma-Aldrich), 500 $\mu$ M IBMX (3-isobutyl1-methyl-xanthine; Sigma-Aldrich) and $2 \mu \mathrm{M}$ rosiglitazone (Molecula; Winborne, UK). Following the 4 day differentiation they were maintained for up to 10 days in postdifferentiation media (renewed every 2-3 days) in which the dexamethasone, IBMX and rosiglitazone were omitted. Differentiation of the SGBS cells from preadipocytes into mature adipocytes was evident from the accumulation of intracellular lipid droplets for which the differentiation rate was $>$ $80 \%$. Cells were harvested in Tri-pure reagent (Roche Diagnostics Limited, Burgess Hill, UK) and RNA was extracted using the manufacturers' method as described below.

\subsection{Real Time Quantitative PCR (RTQ-PCR; Taqman System)}

Total RNA was extracted using the RNeasy Lipid tissue mini kit followed by incubation with RNase free DNase for DNA-free RNA, following the manufacturer's instructions (Qiagen, Crawley, West Sussex).

RNA was quantified on the Agilent 2100 Bioanalyser (Agilent Technologies, South Queensferry, West Lothian). This also shows the quality of the RNA extracted from the tissues. Only RNA showing no degradation was processed further. Reverse transcription was carried out on 3-5 $\mu \mathrm{g}$ of RNA using the Superscript first strand synthesis system (Invitrogen: 12371-019) according to the manufacturer's instructions. The cDNA was amplified by PCR using human specific primers for SLPI (Applied Biosystems: Hs 00268204_m1), reverse transcription mixture and oligonucleotides with a final concentration of $300 \mathrm{nmol} / \mathrm{l}$ of primers and $200 \mathrm{nmol} / \mathrm{l}$ of TaqMan hybridization probe added to the $10 \mu 1$ reaction mix.

PCR was performed under the following conditions; step 1: $95{ }^{\circ} \mathrm{C}$ (20seconds) for 1 cycle and step 2 : $95{ }^{\circ} \mathrm{C}$ (3 seconds), $60{ }^{\circ} \mathrm{C}$ (30 seconds) for 40 cycles. All samples were run in triplicate and were all within the standard curve. A serial dilution of known copy numbers of a PCR product served as reference (standard curve) providing a relative quantification of the unknown samples. Target gene expression was related to the housekeeping genes, ribosomal protein L30 (RPL30; Primers obtained from Applied Biosystems cat. number Hs $00265497 \mathrm{ml}$ ) and beta-2-microglobulin (B2M; Applied Biosystems: Hs 00187842_ m1), following the manufacturer's instructions. Similar results were obtained with both control genes (data only shown for B2M).

All of the primers and probes were purchased from Applied Biosystems as TaqMan Gene Expression Assays which have been validated by Applied Biosystems. Further details of all the primers are available at the Applied Biosystems website under the catalogue numbers provided. Suitable controls were carried out to eliminate any potential for spurious amplification from contaminating genomic DNA.

\subsection{Statistical Analysis}

Comparisons between groups were made using unpaired Student's t-tests. Results were considered statistically significant when $\mathrm{p} \leq 0.05$. Where appropriate the data were also analysed by one- way ANOVA using GenStat version 11.

\section{RESULTS}

\subsection{Expression of SLPI in Lean/Overweight, Obese and Obese Diabetic Male Volunteers}

\subsection{Changes in Circulating SLPI}

To determine if SLPI is regulated by changes in obesity and/or diabetes we determined the circulating levels of SLPI by ELISA in lean/overweight volunteers $(n=13)$, obese volunteers $(n=10)$ and a diabetic obese group $(n=11)$.

Table 1 summarises the results for the anthropometric, clinical and biochemical parameters in the three groups of 
volunteers. Whilst there were no significant differences in age or height of the volunteers, they had significantly different waist circumference (1-way ANOVA; $\mathrm{p}<0.001$ ), BMI $(p<0.001), \%$ body fat $(p<0.001)$, and waist/hip ratio $(p<0.001)$ (Table 1). All of these values were greater in the obese groups. In addition, markers of insulin resistance between the three groups were significantly different, namely oral glucose tolerance test (OGTT) at 0 and 2 hours $(p<0.001)$, insulin $(p<0.001)$, HOMA-IR $(p<0.001)$ and serum triglycerides $(p<0.05)$. These values increased from the lean overweight group through to the obese and obese diabetic groups (Table $\mathbf{1}$ ).
Circulating SLPI shows a small but significant increase in obese $(11 \% ; \mathrm{p} \leq 0.05)$ and obese diabetic volunteers $(16 \% ; \mathrm{p} \leq 0.001)$ when compared with lean/overweight volunteers (ANOVA $p=0.009$ ). There was no significant difference between the obese and obese diabetic group (Fig 1a). Similarly, as expected, both plasma leptin (Fig 1b) and CRP (Fig 1c) increased in obese (Leptin: $400 \%, \mathrm{p} \leq 0.01$; CRP: $350 \%, \mathrm{p} \leq 0.001)$ and obese diabetic volunteers (Leptin: $490 \%, \mathrm{p} \leq 0.001$; CRP: $390 \%, \mathrm{p} \leq 0.05$ ) respectively when compared with lean/overweight volunteers. However again there was no significant difference between the obese and obese diabetic groups (Fig 1).

$$
\text { a) SLPI }
$$

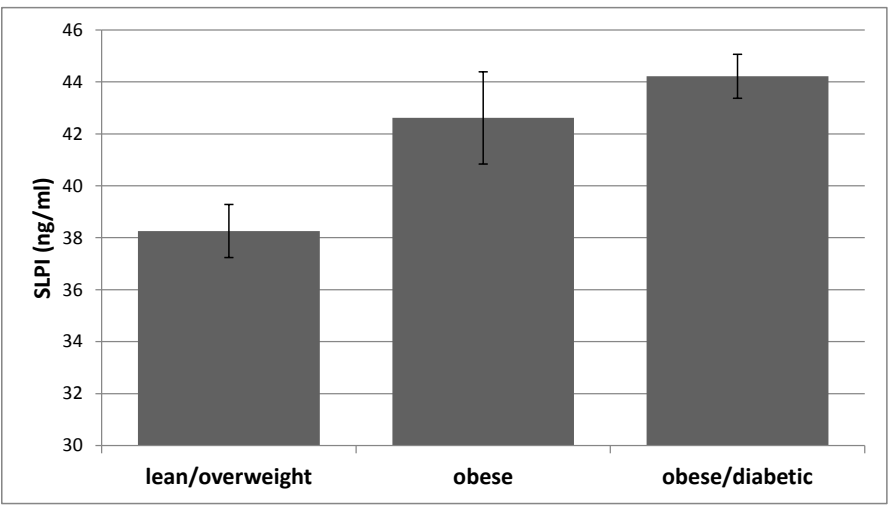

b) Leptin

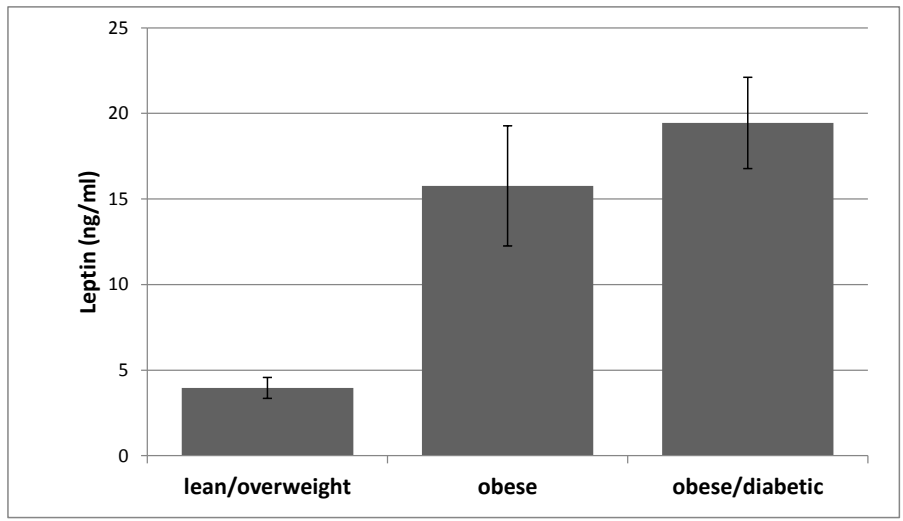

c) C-Reactive Protein (CRP)

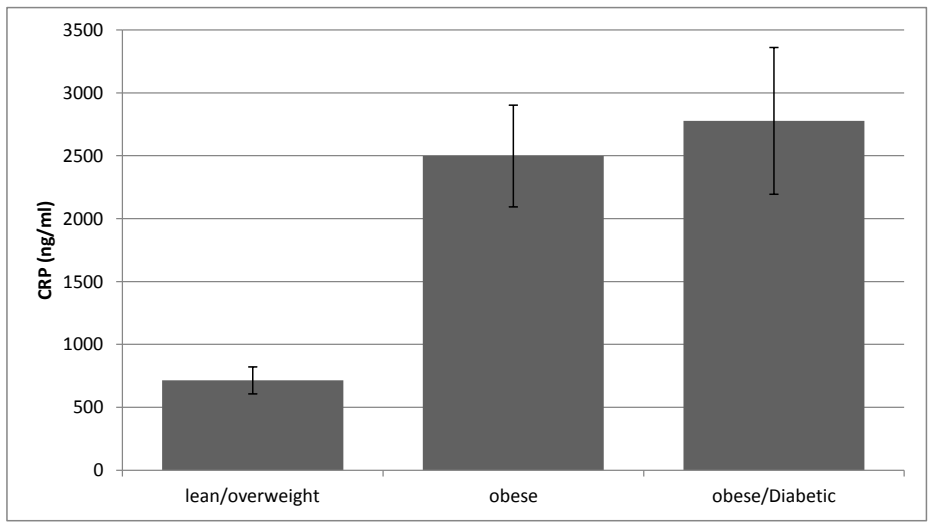

Fig. (1). Change in plasma a) SLPI, b) leptin and c) C-reactive protein in lean/overweight ( $\mathrm{n}=10)$, obese ( $\mathrm{n}=13)$ and obese/diabetic volunteers $(\mathrm{n}=11)$ as determined by ELISA. $* \mathrm{P}<0.05, * * \mathrm{P}<0.01, * * * \mathrm{P}<0.001$. 
There was no significant correlations between plasma SLPI with any of the parameters analysed, including BMI ( $\mathrm{r}$ $=0.25)$, cholesterol $(\mathrm{r}=0.14)$, fasting glucose $(\mathrm{r}=0.38)$, and leptin $(r=0.43)$. Similarly there was no significant correlation between plasma SLPI with any of these parameters in each of the individual groups lean/overweight, obese or obese diabetic.

\subsection{Changes in Adipose Tissue SLPI mRNA in Lean/ Overweight, Obese and Obese Diabetic Volunteers}

To determine if the changes in plasma SLPI observed in the lean/overweight, obese and obese diabetic volunteers correspond to changes in the expression of SLPI mRNA in adipose tissue; we carried out real-time PCR (Fig 2) on the subcutaneous adipose tissue samples obtained from the same volunteers. SLPI in the subcutaneous adipose tissue shows a significant increase in obese $(800 \% ; \mathrm{p} \leq 0.01)$ and obese diabetic volunteers $(500 \% ; \mathrm{p} \leq 0.001)$ when compared with lean/overweight volunteers (Fig. 2). As with the plasma levels of SLPI there was no significant difference between the obese and obese diabetic volunteers.

\subsection{Regulation of SLPI mRNA by Inflammation, Insulin and Glucose in the Human Adipocyte SGBS Cell Line}

To determine if the expression of SLPI is regulated by inflammatory stimuli, insulin or glucose, fully differentiated human adipocytes were incubated for $24 \mathrm{hrs}$ in the presence of one of the following: IL-6 (10 or 100ng/ml), TNF alpha (1 or $10 \mathrm{ng} / \mathrm{ml})$, LPS $(100 \mathrm{ng} / \mathrm{ml})$, insulin $(1$ or $10 \mathrm{mM})$ or glucose ( 5 or $25 \mathrm{mM}$; Fig 3a). Following the $24 \mathrm{hr}$ incubation, SLPI mRNA expression in the human adipocytes was determined by real-time PCR.

The addition of inflammatory cytokines IL-6 (10 or 100 $\mathrm{ng} / \mathrm{ml}$ ) and TNF alpha (1 or $10 \mathrm{ng} / \mathrm{ml}$ ) significantly increased the expression of SLPI in the adipocyte cells when compared with the untreated control cells. At the lowest concentration, IL-6 $(10 \mathrm{ng} / \mathrm{ml})$ and TNF alpha $(1 \mathrm{ng} / \mathrm{ml})$ increased SLPI mRNA $318 \%(p=0.009)$ and $279 \%(p=0.005)$ respectively when compared with the untreated control cells (Fig 3a). The endotoxin LPS (100 ng/ml) increased SLPI expression 318\% $(\mathrm{p}=0.021)$ compared with the untreated control cells (Fig 3a). The addition of insulin (1 or $10 \mathrm{mM})$ and glucose (5 or $25 \mathrm{mM}$ ) also significantly increased SLPI mRNA expression in the adipocytes. At the lowest concentrations insulin $(1 \mathrm{mM})$ and glucose $(5 \mathrm{mM})$ increased SLPI mRNA by $321 \%$ $(p=0.018)$ and $246 \%(p=0.031)$ respectively when compared with the untreated control cells (Fig 3a). Using one way analysis of variance there is a significant effect of treatment ( $\mathrm{p}=0.037$; Fig. 3a).

As a control we also examined the regulation of SLPI by inflammatory stimuli, insulin or glucose in undifferentiated adipocytes by incubating them for $24 \mathrm{hrs}$ in the presence of one of the following: TNF alpha (10 ng/ml), LPS (100 $\mathrm{ng} / \mathrm{ml})$, insulin (1 or $10 \mathrm{mM})$ or glucose $(5$ or $25 \mathrm{mM}$; Fig $3 \mathbf{b})$. There was no increase in SLPI mRNA in the undifferentiated human adipocytes with any of the inflammatory stimuli, insulin or glucose when compared with the untreated control cells. However, there was a significant decrease in SLPI mRNA in the adipocytes with the addition of TNF alpha $(30 \% ; 10 \mathrm{ng} / \mathrm{ml} ; \mathrm{p}=0.049)$ and LPS $(42 \% ; 100 \mathrm{ng} / \mathrm{ml} ; \mathrm{p}$ $=0.03$ ) when compared with the untreated control cells (Fig 3b). Using one way analysis of variance there is also a significant effect of treatment ( $\mathrm{p}=0.002$; Fig $3 \mathbf{b}$ ).

\section{DISCUSSION}

Obesity and its co-morbidities, such as diabetes, are associated with a state of chronic, mild inflammation. It is thought that this inflammation within adipose tissue plays a causal role in the initiation and development of the diseases

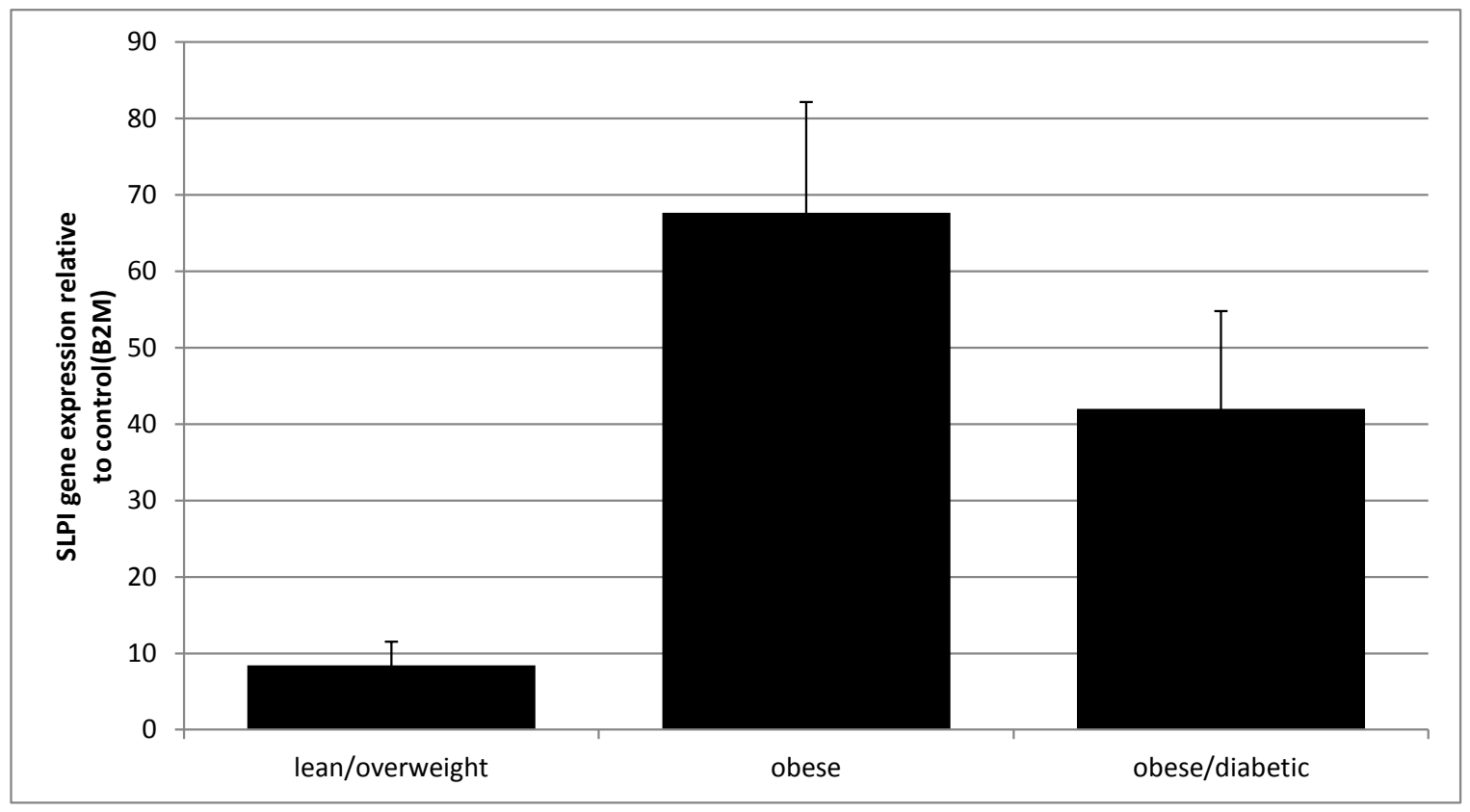

Fig. (2). Change in the of expression of SLPI m RNA form subcutaneous fat biopsies taken from lean/overweight ( $\mathrm{n}=13)$, obese ( $\mathrm{n}=10)$ and obese/diabetic $(n=11)$ volunteers as determined by real time PCR expressed relative to Beta- 2 microglobulin $(B 2 M) n=3$ for each point $+/$ S.E.M. $* \mathrm{P}<0.05, * * \mathrm{P}<0.01, * * * \mathrm{P}<0.001$. 
linked to obesity $[2,17,18]$. Thus, there is a considerable focus on establishing the links between specific inflammation-related adipokines and the development of obesityassociated disease. Within WAT it has been suggested that inflammation is fundamentally a response to one or more of the following (i) oxidative stress [19]; (ii) endoplasmic reticulum stress [20,21]; or (iii) local hypoxia [22]. There are a lot of studies which show that inflammation occurs in adipose tissue, however an inflammatory response is often accompanied by a parallel activation of feedback mechanisms that suppress the inflammatory response [23, 24]. Although this has not been very well studied in adipose tissue, there is evidence that it does occur. For example, the LPS induced activation of the NF- $\mathrm{kB}$ and MAPK pathways in human preadipocytes is transient and rapidly returns to baseline [25].

SLPI possesses an immunomodulatory role in that it can regulate various factors responsible for causing inflammation such as the transcription nuclear factor $\kappa B(N F-\kappa B)[7,9$, 10]. SLPI is a component of the innate host defence that maintains a balance between protective inflammatory responses and uncontrolled inflammation [12]. For example, the exogenous administration of recombinant SLPI ameliorates the inflammatory responses seen in models of both stroke and of acute arthritis [26, 27]. The increase in SLPI in

a)

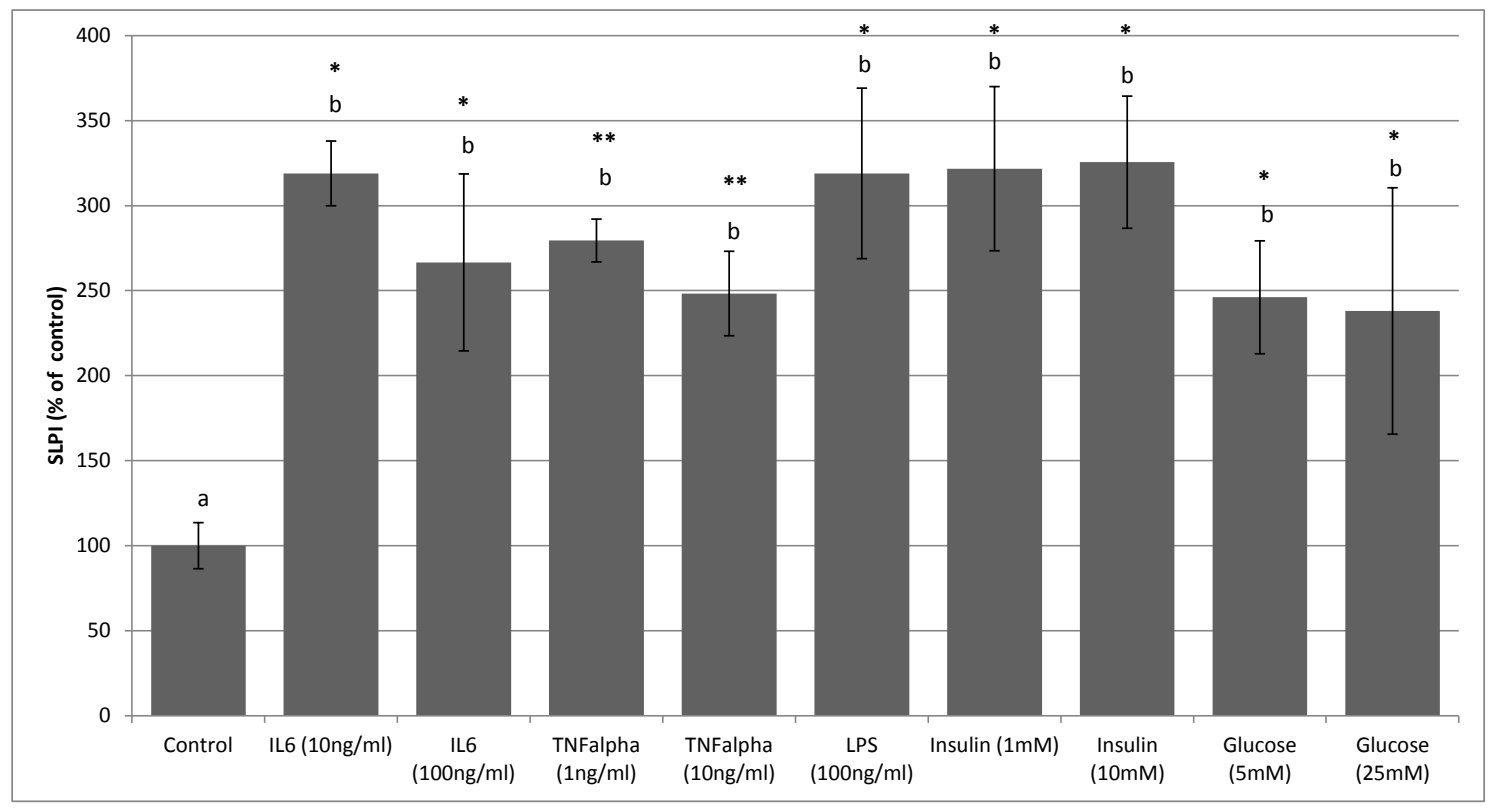

b)

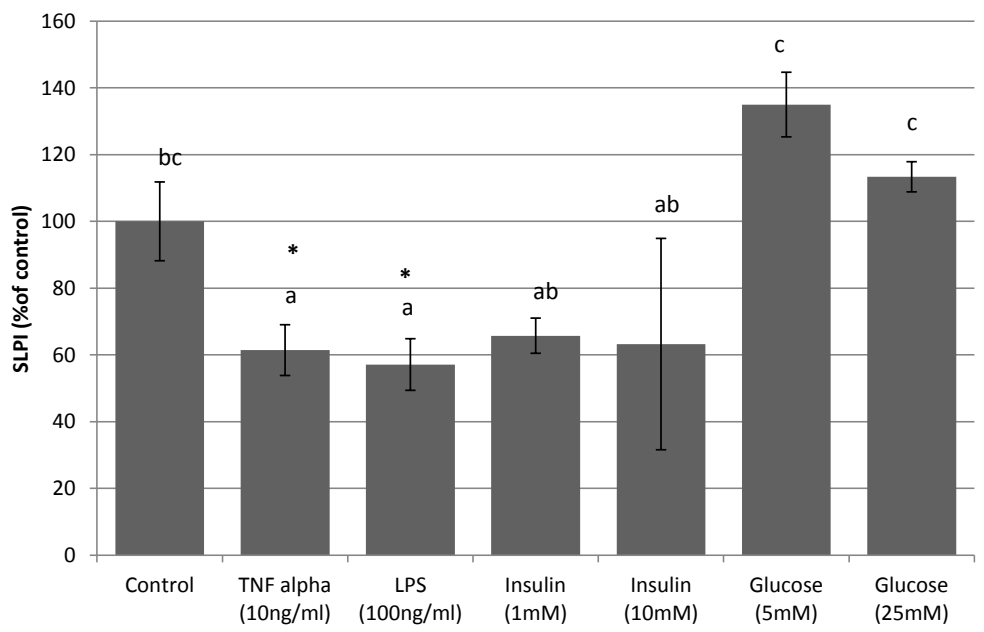

Fig. (3). The effect of either IL6 (10 or $100 \mathrm{ng} / \mathrm{ml})$, TNF alpha ( 1 or $10 \mathrm{ng} / \mathrm{ml})$, LPS (100ng/ml), insulin ( 1 or $10 \mathrm{mM})$ or glucose $(5$ or $25 \mathrm{mM})$ on the expression of SLPI mRNA in a) differentiated primary cultures of human adipocytes or $\mathbf{b}$ ) human preadipocytes cells compared with the untreated control cells. SLPI mRNA was determined by real-time quantitative PCR. Results are expressed as a percentage of the control, $\mathrm{n}=3$ for each point \pm S.E.M, related to the expression of a control gene B2M. Effect of treatment $\mathrm{p}=0.037$ for differentiated adipocytes and 0.002 for preadipocytes determined by ANOVA. Different letters indicate parameters that were significantly different from one another by ANOVA. Control vs treatment t-test: $* \mathrm{P}<0.05, * * \mathrm{P}<0.01, * * * \mathrm{P}<0.001$. This was replicated in independent amplifications. 
WAT reported in this study, in obese volunteers may therefore act locally to antagonise the inflammation in this tissue. The increase in the expression of SLPI is likely to result in an increased secretion of SLPI protein from the adipose tissue into the circulation, where it may also act as an endocrine factor. It may therefore, at least in part, contribute to the increase in circulating SLPI that we observe in the obese volunteers compared with the lean/overweight volunteers. A similar increase in the expression of SLPI in adipose tissue has recently been reported in mice fed a high fat diet for 12 weeks compared with those on a low fat diet [28]. However this study did not look at circulating levels of SLPI.

There was no increase in either circulating SLPI or expression of SLPI in adipose tissue of diabetic volunteers compared with obese volunteers. There was also no significant corresponding change in the inflammatory markers, leptin or CRP, in these diabetic volunteers compared with the obese volunteers. In a recent study SLPI, at least in the plasma, has been shown to be correlated with progressive metabolic dysfunction [29]. It may be that the inflammatory profile of these diabetic volunteers who are controlling their diabetes by diet or metformin is not sufficient to see any corresponding changes in the expression of SLPI when compared with the obese volunteers. Alternatively the number of subjects in these subgroups may have been insufficient to detect between-group differences.

We have previously shown that SLPI is expressed more highly in omental WAT compared with subcutaneous WAT [6]. As omental WAT is more closely associated with the comorbidities associated with obesity than subcutaneous depots, it supports an anti-inflammatory role for SLPI in adipose tissue to counter act the inflammation associated with obesity. In keeping with this, we show here that inflammatory stimuli LPS or inflammatory cytokines such as IL6 and TNFalpha at physiological levels stimulated an increase in SLPI gene expression in mature adipocytes. There is no stimulation with these inflammatory factors in the preadipocytes which also express SLPI, albeit at a reduced level [6]. Indeed, we show there is a significant decrease in SLPI expression in preadipoctes in response to LPS and TNFalpha. This does not exclude the possibility that other cells in the stromal vascular fraction of adipose tissue such as endothelial cells, fibroblasts or macrophages, also secrete SLPI in response to an inflammatory response. SLPI is induced by the endotoxin LPS and other inflammatory cytokines including IL-1 and TNF alpha in macrophages and epithelial cells $[30,31]$. We also show that both insulin and glucose increase SLPI expression in adipocytes; again this may be part of a counter regulation mechanism to reduce the inflammation associated with obesity.

In conclusion, circulating SLPI and gene expression in the subcutaneous adipose tissue is expressed more in obese compared with lean/overweight men. SLPI expressed in adipose tissue may play a local or paracrine anti inflammatory role in the regulation of the low grade inflammatory response associated with obesity, which ultimately may not be able to cope with the increasing inflammation, leading to diabetes.

\section{FUNDING}

This work was supported by the Scottish Government Rural and Environment Science and Analytical Services (RESAS).

\section{ACKNOWLEDGEMENTS}

We are grateful to Prof M. Wabitsch, University of Ulm, Germany for providing the SGBS cells. We are grateful to the Health Human Nutrition Unit for their assistance in the human studies and to Biomathematics and Statistics Scotland for their assistance in the data analysis.

\section{DECLARATION OF INTEREST}

We declare there is no conflict of interest that could be perceived as prejudicing the impartiality of the research reported.

\section{CONTRIBUTION OF AUTHORS}

$\mathrm{KM}$ and $\mathrm{MC}$ performed all of the experiments calculated results and contributed to preparation of manuscript. $\mathrm{NH}$ conceived the experimental design and goals, contributed to the analysis of data and was the main author of the manuscript.

\begin{tabular}{|c|c|c|}
\hline \multicolumn{3}{|c|}{ ABBREVIATIONS } \\
\hline SLPI & $=$ & Secretory leukocyte peptidase inhibitor \\
\hline CRP & $=$ & C-reactive peptide \\
\hline IL-6 & $=$ & Interleukin 6 , \\
\hline TNF alpha & $=$ & Tumour necrosis factor alpha \\
\hline MCP-1 & $=$ & Monocyte chemotactic protein-1 \\
\hline WAT & $=$ & White adipose tissue \\
\hline SGBS & $=$ & Simpson-Golabi-Behmel syndrome \\
\hline OGTT & $=$ & Oral Glucose Tolerance Testing \\
\hline LDL & $=$ & Low-density lipoprotein \\
\hline HDL & $=$ & High-density lipoprotein \\
\hline CRP & $=$ & C-reactive peptide \\
\hline IBMX & $=$ & 3-isobutyl-1-methyl-xanthine \\
\hline RTQ-PCR & $=$ & Real Time Quantitative PCR \\
\hline RPL30 & $=$ & Ribosomal protein L30 \\
\hline B2M & $=$ & Beta-2-microglobulin \\
\hline ANOVA & $=$ & Analysis of variance \\
\hline LPS & $=$ & Lipopolysaccharide \\
\hline$N F-\kappa B$ & $=$ & Transcription nuclear factor $\kappa \mathrm{B}$ \\
\hline
\end{tabular}

\section{REFERENCES}

[1] Wellen KE, Hotamisligil GS. Inflammation, stress, and diabetes. J Clin Invest 2005; 115(5): 1111-9.

[2] Hotamisligil GS. Inflammation and metabolic disorders. Nature 2006; 444(7121): 860-7.

[3] Trayhurn P, Wang B, Wood IS. Hypoxia in adipose tissue: A basis for the dysregulation of tissue function in obesity? Br J Nutr 2008; 100(2): 227-35.

[4] Chan DC, Watts GF, Sussekov AV, et al. Adipose tissue compartments and insulin resistance in overweight-obese Caucasian men. Diabetes Res Clin Pract 2004; 63(2): 77-85.

[5] Misra A, Vikram NK. Clinical and pathophysiological consequences of abdominal adiposity and abdominal adipose tissue depots. Nutrition 2003; 19(5): 457-66. 
[6] Hoggard N, Cruickshank M, Moar K, et al. Using gene expression to predict differences in the secretome of human omental vs subcutaneous adipose tissue. Obesity 2012; 20(6): 1158

[7] Doumas S, Kolokotronis A, Stefanopoulos P. Anti-inflammatory and antimicrobial roles of secretory leukocyte protease inhibitor. Infect Immun 2005; 73(3): 1271-4.

[8] Moreau T, Baranger K, Dadé S, et al. Multifaceted roles of human elafin and secretory leukocyte proteinase inhibitor (SLPI), two serine protease inhibitors of the chelonianin family. Biochimie 2008; 90(2): 284-95.

[9] Lee J, Chae S, Cho J, et al. Expression of secretory leukocyte protease inhibitor in middle ear cholesteatoma. Euro Arch Oto-RhinoLaryngol 2006; 263(12): 1077-81.

[10] Weldon S, McGarry N, Taggart CC, et al. The role of secretory leucoprotease inhibitor in the resolution of inflammatory responses. Biochem Soc Trans 2007; 35(2): 273-6.

[11] Ashcroft GS, Lei K, Jin W, et al. Secretory leukocyte protease inhibitor mediates non-redundant functions necessary for normal wound healing. Nat Med 2000; 6(10): 1147-53.

[12] Williams SE, Brown TI, Roghanian A, et al. SLPI and elafin: One glove, many fingers. Clin Sci 2006; 110(1): 21-35.

[13] Janssen I, Katzmarzyk PT, Ross R. Waist circumference and not body mass index explains obesity-related health risk. Am J Clin Nutr 2004; 79(3): 379-84.

[14] Hoggard N, Hunter L, Duncan JS, et al. Regulation of adipose tissue leptin secretion by $\alpha$-melanocyte-stimulating hormone and agouti-related protein: Further evidence of an interaction between leptin and the melanocortin signalling system. J Mol Endocrinol 2004; 32(1): 145-53.

[15] Matthews DR, Hosker JP, Rudenski AS, et al. Homeostasis model assessment: insulin resistance and beta-cell function from fasting plasma glucose and insulin concentrations in man. Diabetologia 1985; 28 (7): 412-9

[16] Fischer-Posovszky P, Newell FS, Wabitsch M, et al. Human SGBS cells - a unique tool for studies of human fat cell biology. Obesity facts 2008; 1(4): 184-9.

[17] Yudkin JS. Adipose tissue, insulin action and vascular disease: Inflammatory signals. Int J Obes 2003; 27(Suppl. 3): S25-8.

[18] Rosen ED, Spiegelman BM. Adipocytes as regulators of energy balance and glucose homeostasis. Nature 2006; 444(7121): 847-53.
[19] Houstis N, Rosen ED, Lander ES. Reactive oxygen species have a causal role in multiple forms of insulin resistance. Nature 2006; 440(7086): 944-8.

[20] Özcan U, Cao Q, Yilmaz E, et al. Endoplasmic reticulum stress links obesity, insulin action, and type 2 diabetes. Science 2004; 306(5695): 457-61.

[21] Gregor MF, Hotamisligil GS. Adipocyte stress: The endoplasmic reticulum and metabolic disease. J Lipid Res 2007; 48(9): 1905-14.

[22] Trayhurn P, Wood IS. Adipokines: Inflammation and the pleiotropic role of white adipose tissue. Br J Nutr 2004; 92(3): 347-55.

[23] Ashino T, Yamanaka R, Yamamoto M, et al. Negative feedback regulation of lipopolysaccharide-induced inducible nitric oxide synthase gene expression by heme oxygenase-1 induction in macrophages. Mol Immunol 2008; 45(7): 2106-15.

[24] Rothlin CV, Ghosh S, Zuniga EI, et al. TAM Receptors Are Pleiotropic Inhibitors of the Innate Immune Response. Cell 2007; 131(6): 1124-36.

[25] Chung S, LaPoint K, Martinez K, et al. Preadipocytes mediate lipopolysaccharide-induced inflammation and insulin resistance in primary cultures of newly differentiated human adipocytes. Endocrinology 2006; 147(11): 5340-51.

[26] Song X, Zeng L, Jin W, et al. Secretory leukocyte protease inhibitor suppresses the inflammation and joint damage of bacterial cell wall-induced arthritis. J Exp Med 1999; 190(4): 535-42.

[27] Wang X, Li X, Xu L, et al. Up-regulation of secretory leukocyte protease inhibitor (SLPI) in the brain after ischemic stroke: Adenoviral expression of SLPI protects brain from ischemic injury. Mol Pharmacol 2003; 64(4): 833-40.

[28] Adapala VJ, Buhman KK, Ajuwon KM. Novel anti-inflammatory role of SLPI in adipose tissue and its regulation by high fat diet. J Inflamm 2011; 8: 5 .

[29] López-Bermejo A, Ortega FJ, Castro A, et al. The alarm secretory leukocyte protease inhibitor increases with progressive metabolic dysfunction. Clinica Chimica Acta 2011; 412(11-12): 1122-6.

[30] Jin F-, Nathan C, Radzioch D, et al. Secretory leukocyte protease inhibitor: A macrophage product induced by and antagonistic to bacterial lipopolysaccharide. Cell 1997; 88(3): 417-26.

[31] Sallenave JM, Shulmann J, Crossley J, et al. Regulation of secretory leukocyte proteinase inhibitor (SLPI) and elastase-specific inhibitor (ESI/elafin) in human airway epithelial cells by cytokines and neutrophilic enzymes. Am J Respir Cell Mol Biol 1994; 11(6): $733-41$.

(C) Hoggard et al.; Licensee Bentham Open

This is an open access article licensed under the terms of the Creative Commons Attribution Non-Commercial License (http://creativecommons.org/licenses/by-nc/3.0/) which permits unrestricted, non-commercial use, distribution and reproduction in any medium, provided the work is properly cited. 